\title{
USING MIND MAPPING TO TEACH SPEAKING SKILL TO THE TENTH GRADE STUDENTS OF MAN PALOPO
}

\author{
Riska $^{1 *}$, Andi Tenrisanna Syam² \\ ${ }^{12}$ State Islamic Institute of Palopo, Indonesia \\ andi_tenrisanna_syam@iainpalopo.ac.id
}

\begin{abstract}
The purpose of this research is to find out whether the students who are taught by using mind mapping have better achievement than the students who were taught by using a nonmapping strategy. This research used a quasi-experimental method. The population of this research consisted of tenth-grade students of MAN Palopo. The writer used purposive sampling, where there were two classes as the sample. They were; class X MIA I and X MIA II. Each class consisted of 30 students. The writer gave pretest and posttest to the studentsthree aspects of speaking skill assessed, namely accuracy, fluency, and comprehensibility. The result of this research shows that the students who were taught by using mind mapping did not have better achievement than the students who were taught by using non-mind mapping. The data showed that t-obtained was higher than t-table ( $\mathrm{t}-\mathrm{o}>\mathrm{t}$-table). The findings of $t$-obtained were 0.216 , whereas the level of significance of 0.05 (5\%) was 2.002 . It means that $2.002 \geq 0.216$. The orienting number of significances showed that $0.830>0.05$. Therefore, the Null Hypothesis (H0) accepted, and the Alternative Hypothesis (H1) rejected. Some problems found by the writer namely, the students switch code to speak up because they did not know the English meaning of the words, the students still read the text to speak because they did not memorize the language pattern that had been given. So, they had difficulties in speaking without reading the text. They felt hungry, tired, and bored in the class, and some of the students had meetings' organization after they were an exam.
\end{abstract}

Keywords: English Language Teaching, Mind Mapping, Teaching Speaking Skills.

\section{INTRODUCTION}

Estiningrum (2015) states that speaking is a productive skill; it is the two-ways process of social communication which includes the use of verbal and non-verbal language to convey meaning. When people have a conversation with others, they include the process of producing language and receiving the message. Speaking is one of the significant elements of means of communication.

There are many problems in the process of learning English. One of them is how to make the students interested in the English lesson, especially for speaking so that the situation in the class can make the students enjoy to learn. Speaking is an essential part of English to communicate or telling something to other people. When people can communicate 
with English, they can inform their idea quickly. Besides, if students always practice speaking English, they will not be shy or nervous when they are speaking in front of the public. So, they are essential parts to make the students interest to improve their speaking skills.

Based on the writer's observation conducted at MAN Palopo, especially in the tenth years. On Friday, 22nd September 2018, the writer interviewed one of the English teachers, and there were 30 tenth-graders. The students learned about speaking, but they did not expand their knowledge, they only learned the basics of English, such as vocabulary. Besides, they just spoke by reading in front of the class. Moreover, some students said that they were difficult to pronounce the word because sometimes they said that the read of the text in English did not appropriate with the writing of the words.

Furthermore, the student's grammar still less so that they were difficult and afraid to speak up. Besides, there a few students who were active in the class. Also, the teacher asked students to memorize some vocabulary as a strategy to overcome the students who have a low vocabulary to speak. On the other hand, the teacher just used a book as a media to teach so that the process of learning monotonous and it makes the students bored. Therefore, the students need to learn by using an interesting technique to make them comfortable and motivated to learn English, especially for speaking. In this case, the writer used mind mapping to make students interest and they understand the materials because in this technique the writer allows the students to inform their idea through the materials that have been prepared by the writer.

Mind mapping is a strategy to activate the right and left brain balance when the teacher taught English. Then, according to Knight (2012), mind maps are unique organizational and creativity that can improve memory, concentration, communication, creativity, and time management. Disadvantages of using mind mapping are each student have variation mind maps so that the teacher unable to handle the students' mind mapping, it will be spending the time to write the words that have not connected with the brain, and so on.

This research findings are different with the previous research. The writer found that mind mapping does not improve students' speaking skill while the previous researchers found that mind mapping improves the students' speaking skills.

\section{METHODS}

The writer used a quasi-experimental design. The writer gave the pretest and posttest to the students. The pretest was given to both classes to measure students' speaking skills before giving the treatment. Then, posttest was given to measure the students' speaking skills after giving the treatment. The students in the experimental class would be taught by using the mind mapping technique in teaching describing especially for describing people and thing. The students in the control class would be taught without using the mind mapping technique. The population of this research was tenth-grade students of MAN Palopo in academic year 2018/2019. The total population was 120 students who were distributed in 3 classes. The writer used purposive sampling because the sample was believed to be a representative population. The writer chose X MIA I as an experimental class and X MIA 2 as 
a control class. Each class consisted of 30 students and the total students were 60 students. There were two instruments of the research, namely speaking test and the video camera. The writer used quantitative analysis by calculating the pretest and posttest score, classifying the score into six levels by using Brown's rubric score, and calculating aveage score, standard deviation, and t-test paired sample using SPSS 20.0.

\section{RESULTS}

\section{The Students' Accuracy Achievement}

The frequency score and the percentage of the students' accuracy in experimental and control classes can be seen in the following tables:

Table 1. The Frequency and Percentage of Students' Achievement in term of Accuracy in Pretest

\begin{tabular}{|c|c|c|c|c|c|}
\hline \multirow{2}{*}{ Classification } & \multirow{2}{*}{ Score } & \multicolumn{2}{|c|}{ Experimental Group } & \multicolumn{2}{|c|}{ Control Group } \\
\hline & & $\mathrm{F}$ & $\%$ & $\mathrm{~F}$ & $\%$ \\
\hline Excellent & $86-100$ & 0 & $0 \%$ & 0 & $0 \%$ \\
\hline Good & $71-85$ & 0 & $0 \%$ & 0 & $0 \%$ \\
\hline Adequate & $56-70$ & 0 & $0 \%$ & 0 & $0 \%$ \\
\hline Inadequate/unsatisfactory & $41-55$ & 2 & $7 \%$ & 2 & $7 \%$ \\
\hline Failing/Unacceptable & $26-40$ & 28 & $93 \%$ & 28 & $93 \%$ \\
\hline Total & & 30 & $100 \%$ & 30 & $100 \%$ \\
\hline
\end{tabular}

Table 1 above illustrates above illustrates that most of the students in the experimental and control class got a low category. The percentage both of classes, classified as inadequate/unsatisfactory achiever was 7\% (2 students) and failing/Unacceptable achiever was $93 \%$ (28 students).

Based on the percentage, both experimental and control classes showed that low achievers were bigger than excellent achievers. It indicated that both of the classes still needed to be improved.

Table 2. The Frequency and Percentage of Students' Achievement in term of Accuracy in Posttest

\begin{tabular}{|c|c|c|c|c|c|}
\hline \multirow{2}{*}{ Classification } & \multirow{2}{*}{ Score } & \multicolumn{2}{|c|}{ Experimental Group } & \multicolumn{2}{|c|}{ Control Group } \\
\hline & & $\mathrm{F}$ & $\%$ & $\mathrm{~F}$ & $\%$ \\
\hline Excellent & $86-100$ & 0 & $0 \%$ & 0 & $0 \%$ \\
\hline Good & $71-85$ & 0 & $0 \%$ & 0 & $0 \%$ \\
\hline
\end{tabular}




\begin{tabular}{llllll} 
Adequate & $56-70$ & 0 & $0 \%$ & 0 & $0 \%$ \\
Inadequate/unsatisfactory & $41-55$ & 2 & $7 \%$ & 2 & $7 \%$ \\
Failing/Unacceptable & $26-40$ & 28 & $93 \%$ & 28 & $93 \%$ \\
\hline Total & & $\mathbf{3 0}$ & $\mathbf{1 0 0 \%}$ & $\mathbf{3 0}$ & $\mathbf{1 0 0 \%}$ \\
\hline
\end{tabular}

Table 2 above illustrates that most of the students in the experimental and control class got a low category. The percentage both of classes, classified as inadequate/unsatisfactory achiever was 7\% (2 students) and failing/Unacceptable achiever was $93 \%$ (28 students).

The score distribution for experimental class and control class on accuracy in the posttest showed there were no any difference scores of the pretest. It can be seen that the score of the control class and experimental class still the same. It means that both of them do not reach better score after giving the treatment.

\section{Students' Fluency Achievement}

The frequency score and the percentage of the students' Fluency in experimental class and control class can be seen in the following tables:

Table 3. The Frequency and Percentage of Students' Achievement in term of Fluency in Pretest

\begin{tabular}{|c|c|c|c|c|c|}
\hline \multirow{2}{*}{ Classification } & \multirow{2}{*}{ Score } & \multicolumn{2}{|c|}{ Experimental Group } & \multicolumn{2}{|c|}{ Control Group } \\
\hline & & $\mathrm{F}$ & $\%$ & $\mathrm{~F}$ & $\%$ \\
\hline Excellent & $86-100$ & 0 & $0 \%$ & 0 & $0 \%$ \\
\hline Good & $71-85$ & 0 & $0 \%$ & 0 & $0 \%$ \\
\hline Adequate & $56-70$ & 0 & $0 \%$ & 0 & $0 \%$ \\
\hline Inadequate/unsatisfactory & $41-55$ & 6 & $20 \%$ & 3 & $10 \%$ \\
\hline Failing/Unacceptable & $26-40$ & 24 & $80 \%$ & 27 & $90 \%$ \\
\hline Total & & 30 & $100 \%$ & 30 & $100 \%$ \\
\hline
\end{tabular}

In table 3 above, most of the students in the experimental and control class were in the low achiever category. The score of the experimental class classified as Inadequate/unsatisfactory achiever was 20\% (6 students) and Failing/Unacceptable achiever was $80 \%(24$ students). While in the control class, classified as Inadequate/unsatisfactory achiever was 10\% (3 students), and Failing/Unacceptable achiever was $90 \%$ (27 students). 
Table 4. The Frequency and Percentage of Students' Achievement in term of Fluency in Posttest

\begin{tabular}{|c|c|c|c|c|c|}
\hline \multirow{2}{*}{ Classification } & \multirow{2}{*}{ Score } & \multicolumn{2}{|c|}{ Experimental Group } & \multicolumn{2}{|c|}{ Control Group } \\
\hline & & $\mathrm{F}$ & $\%$ & $\mathrm{~F}$ & $\%$ \\
\hline Excellent & $86-100$ & 0 & $0 \%$ & 0 & $0 \%$ \\
\hline Good & $71-85$ & 0 & $0 \%$ & 0 & $0 \%$ \\
\hline Adequate & $56-70$ & 2 & $7 \%$ & 3 & $10 \%$ \\
\hline Inadequate/unsatisfactory & $41-55$ & 28 & $93 \%$ & 27 & $90 \%$ \\
\hline Failing/Unacceptable & $26-40$ & 0 & $0 \%$ & 0 & $0 \%$ \\
\hline Total & & 30 & $100 \%$ & 30 & $100 \%$ \\
\hline
\end{tabular}

Table 4 above shows that the students' achievements in the fluency category in experimental and control classes did not improve after the treatment. The value percentage of both students' class generally tends on the inadequate/ unsatisfactory achiever category. We can see that adequate achiever was 7\% (2 students), inadequate/unsatisfactory achiever was 93\% (28 students), and excellent, good, and failing/unacceptable achiever was none or $0 \%$. While in the control class, none of them was classified as excellent, good, and failing/unacceptable achiever. Next, inadequate/unsatisfactory achiever was $7 \%$ (2 students), and adequate achiever was $90 \%$ (27 students).

\section{Students' Comprehensibility Achievement}

The frequency score and the percentage of the students' comprehensibility in the experimental class and control class can be seen in the following tables.

Table 5. The Frequency and Percentage of Students' Achievement in term of Comprehensibility in Pretest

\begin{tabular}{|c|c|c|c|c|c|}
\hline \multirow{2}{*}{ Classification } & \multirow{2}{*}{ Score } & \multicolumn{2}{|c|}{ Experimental Group } & \multicolumn{2}{|c|}{ Control Group } \\
\hline & & $\mathrm{F}$ & $\%$ & $\mathrm{~F}$ & $\%$ \\
\hline Excellent & $86-100$ & 0 & $0 \%$ & 0 & $0 \%$ \\
\hline Good & $71-85$ & 0 & $0 \%$ & 0 & $0 \%$ \\
\hline Adequate & $56-70$ & 0 & $0 \%$ & 0 & $0 \%$ \\
\hline Inadequate/unsatisfactory & $41-55$ & 11 & $37 \%$ & 5 & $17 \%$ \\
\hline Failing/Unacceptable & $26-40$ & 19 & $63 \%$ & 25 & $83 \%$ \\
\hline Total & & 30 & $100 \%$ & 30 & $100 \%$ \\
\hline
\end{tabular}


Table 5 shows that most of the students in the experimental and control class were in an inferior achiever category. In experimental class, none of them was classified as an excellent, adequate, and good achiever. Furthermore, inadequate/unsatisfactory achiever was 37\% (11 students), and Failing/Unacceptable achiever was 63\% (19 students). While in the control class, none of them was classified as excellent, adequate, and good achiever. Next, Inadequate/unsatisfactory achiever was 17\% (5 students), and Failing/Unacceptable achiever was $83 \%$ (25 students).

Table 6. The Frequency and Percentage of Students' Achievement in term of Comprehensibility in Posttest

\begin{tabular}{|c|c|c|c|c|c|}
\hline \multirow{2}{*}{ Classification } & \multirow{2}{*}{ Score } & \multicolumn{2}{|c|}{ Experimental Group } & \multicolumn{2}{|c|}{ Control Group } \\
\hline & & $\mathrm{F}$ & $\%$ & $\mathrm{~F}$ & $\%$ \\
\hline Excellent & $86-100$ & 0 & $0 \%$ & 0 & $0 \%$ \\
\hline Good & $71-85$ & 0 & $0 \%$ & 0 & $0 \%$ \\
\hline Adequate & $56-70$ & 2 & $7 \%$ & 2 & $7 \%$ \\
\hline Inadequate/unsatisfactory & $41-55$ & 28 & $93 \%$ & 28 & $93 \%$ \\
\hline Failing/Unacceptable & $26-40$ & 0 & $0 \%$ & 0 & $0 \%$ \\
\hline Total & & 30 & $100 \%$ & 30 & $100 \%$ \\
\hline
\end{tabular}

Table 6 shows that the students' achievements in experimental and control classes in terms of comprehensibility were not improving after the treatment. The students' percentage of both classes generally tends to be inadequate/unsatisfactory achiever category. The percentage of experimental and control class, where inadequate/unsatisfactory achiever was 7\% (2 students) and failing/Unacceptable achiever was $93 \%$ (28 students).

\section{Scoring Classifications of the Students' Pretest in Control and Experimental Classes}

Based on the data in Table 7 below, the result of pretest in experimental and control class was no one student got "excellent", "good", "adequate", and "Inadequate/unsatisfactory". Then, there were 30 or $100 \%$ of students got "Failing/Unacceptable".

The comparison between pretest and posttest result showed that there was no significant difference in students' speaking skills of both classes. The writer concluded that most of the students were classified as "Failing/Unacceptable". 
Table 7. The Rate Percentage and Frequency of Students' Pretest Scores in Experimental and Control Class

\begin{tabular}{|c|c|c|c|c|c|}
\hline \multirow{2}{*}{ Classification } & \multirow{2}{*}{ Score } & \multicolumn{2}{|c|}{ Experimental Group } & \multicolumn{2}{|c|}{ Control Group } \\
\hline & & $\mathrm{F}$ & $\%$ & $\mathrm{~F}$ & $\%$ \\
\hline Excellent & $86-100$ & 0 & $0 \%$ & 0 & $0 \%$ \\
\hline Good & $71-85$ & 0 & $0 \%$ & 0 & $0 \%$ \\
\hline Adequate & $56-70$ & 0 & $0 \%$ & 0 & $0 \%$ \\
\hline Inadequate/unsatisfactory & $41-55$ & 0 & $0 \%$ & 0 & $0 \%$ \\
\hline Failing/Unacceptable & $26-40$ & 30 & $100 \%$ & 30 & $100 \%$ \\
\hline Total & & 30 & $100 \%$ & 30 & $100 \%$ \\
\hline
\end{tabular}

\section{Scoring Classifications of the Students' Posttest in Control and Experimental Classes}

The result of posttest of experimental and control classes was none or $0 \%$ student got "excellent, good, adequate, and inadequate/unsatisfactory", and there were 30 or 100\% students got "failing/unacceptable"

The scores of students' posttest in the experimental and control class shows that there was no significant difference. It was proved by the result of the posttest in both classes that show most of the students were classified as Failing/Unacceptable.

Table 8. The Rate Percentage and Frequency of Students' Posttest Scores in Experimental and Control Class

\begin{tabular}{|c|c|c|c|c|c|}
\hline \multirow{2}{*}{ Classification } & \multirow{2}{*}{ Score } & \multicolumn{2}{|c|}{ Experimental Group } & \multicolumn{2}{|c|}{ Control Group } \\
\hline & & $\mathrm{F}$ & $\%$ & $\mathrm{~F}$ & $\%$ \\
\hline Excellent & $86-100$ & 0 & $0 \%$ & 0 & $0 \%$ \\
\hline Good & $71-85$ & 0 & $0 \%$ & 0 & $0 \%$ \\
\hline Adequate & $56-70$ & 0 & $0 \%$ & 0 & $0 \%$ \\
\hline Inadequate/unsatisfactory & $41-55$ & 0 & $0 \%$ & 0 & $0 \%$ \\
\hline Failing/Unacceptable & $26-40$ & 30 & $100 \%$ & 30 & $100 \%$ \\
\hline Total & & 30 & $100 \%$ & 30 & $100 \%$ \\
\hline
\end{tabular}

\section{The Mean Score and Standard Deviation of Students' Pretest and Posttest}

Based on the table below, the writer presented the mean score and standard deviation of the students' pretest and posttest for experimental class and control class. 
Table 9. The Mean Score and Standard Deviation of Students' Pretest and Posttest

\begin{tabular}{lccccccc}
\hline & $\mathrm{N}$ & Minimum & Maximum & Sum & \multicolumn{2}{c}{ Mean } & Std. Deviation \\
\cline { 2 - 8 } & Statistic & Statistic & Statistic & Statistic & Statistic & $\begin{array}{c}\text { Std. } \\
\text { Error }\end{array}$ & Statistic \\
\hline $\begin{array}{l}\text { Pretest } \\
\text { experiment }\end{array}$ & 30 & 17 & 28 & 601 & 20.03 & .813 & 4.453 \\
$\begin{array}{l}\text { Posttest } \\
\text { experiment }\end{array}$ & 30 & 28 & 44 & 892 & 29.73 & .688 & 3.769 \\
$\begin{array}{l}\text { Pretest } \\
\text { control } \\
\begin{array}{l}\text { Posttest } \\
\text { control }\end{array}\end{array}$ & 30 & 17 & 33 & 569 & 18.97 & .873 & 4.781 \\
$\quad \begin{array}{l}\text { Valid N } \\
\text { (listwise) }\end{array}$ & 30 & 28 & 44 & 886 & 29.53 & .621 & 3.401 \\
\hline
\end{tabular}

The table showed that before and after giving the treatment, the main score of the experimental class and control class was mostly in the same score. It means that there is no improvement after giving the treatment.

The table showed that there were 30 students as respondents in each class, the symbol is N. Next, the high score of experimental class in pretest was 28 and for Control Class was 33, and then the lowest score for Experimental class and Control Class in Pretest was same, they were 17. Besides, the mean score of the experimental class was 20.03 with a standard deviation was 4.45 and the mean score for Control Class was 18.97 with a standard deviation was 4.78 .

The main score both of classes was not different after giving the treatment. We can see in the table that the high score of the experimental class in the posttest was 44 while the high score of the control class was 44 . Besides, the lowest score for the experimental class in the posttest was 28 and for control class was 28. Furthermore, the mean score for the Experimental class in the posttest was 29.73 with the standard deviation was 3.76, and the mean score for control class was 29.53, with a standard deviation of 3.40 . It means that the mean score of the experimental class is higher with the control class $(29.73>29.53)$.

\section{Test of Significance}

Based on the table below (mean score difference of control and experimental class), we can see that both of them did not have a significant difference.

Table 10. The t-test of Pretest for both Classes 


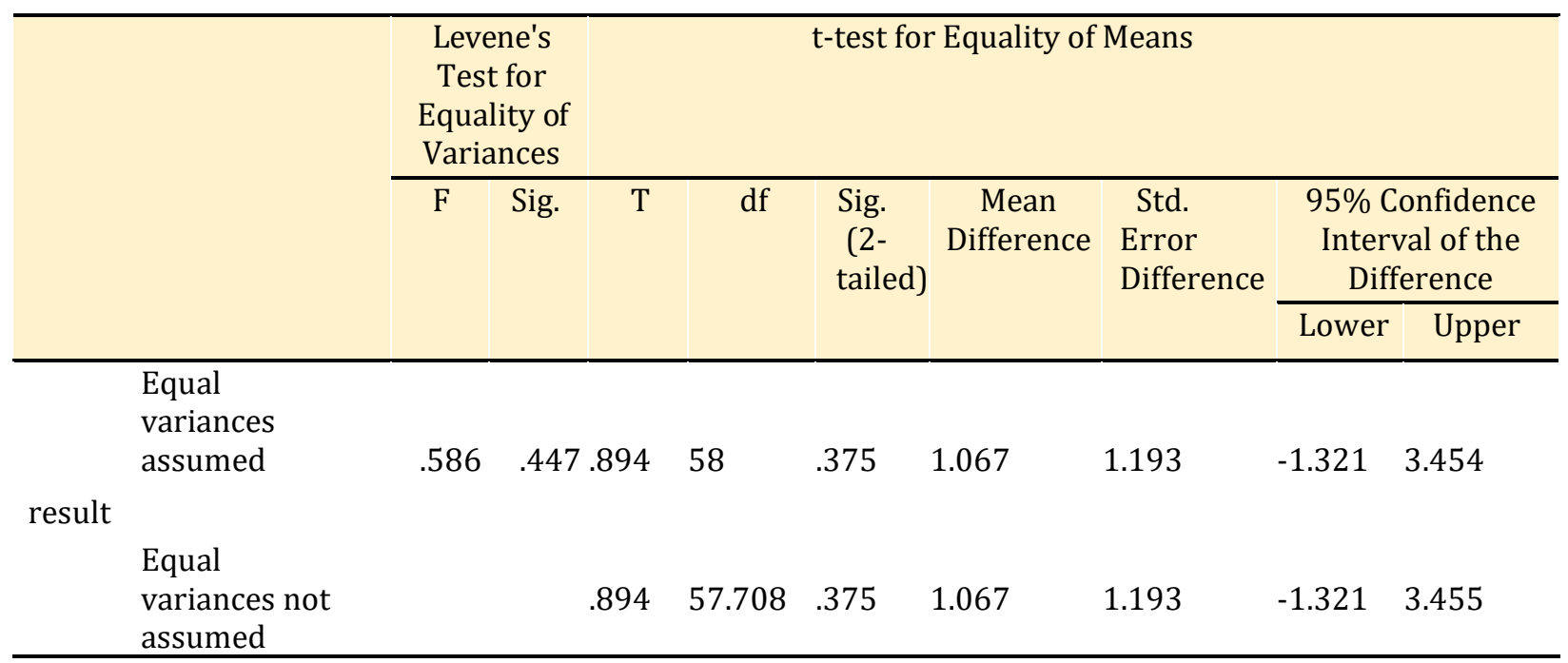

From the table 11 below, the output of the independent sample test showed that the T-Test result was 0.216 with its $\mathrm{df}$ was 58 with the mean score were 0.830 mean difference was 0.200 .

Table 11. The t-test of Posttest for both Classes

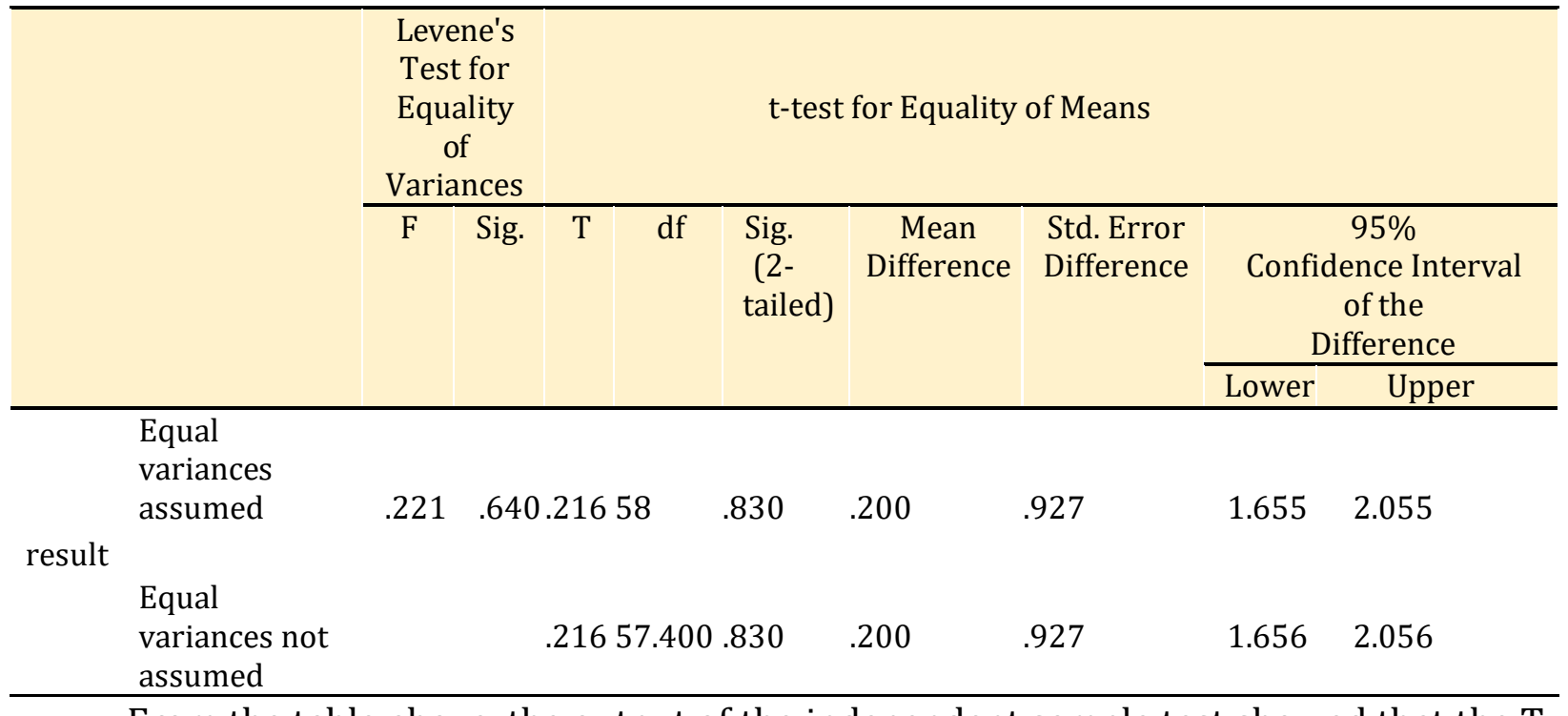

From the table above, the output of the independent sample test showed that the TTest result was 0.21 with its df was 58 with the mean score were 0.830 mean difference was 0.20 . Thus, in interpreting t-obtained, the writer used two ways:

1. By comparing t-obtained to t-table, from df 58 , the level of significance $5 \%$ with $\mathrm{df}=58$, got $2,002 \geq 0.216$. It means that the Null Hypothesis $\left(\mathrm{H}_{0}\right)$ was accepted, while the Alternative Hypothesis $\left(\mathrm{H}_{1}\right)$ was rejected.

2. By orientation number of significant. If the probability $>0.05$, the Null Hypothesis $\left(\mathrm{H}_{0}\right)$ is accepted. If probability $<0.05$, the Alternative Hypothesis $\left(\mathrm{H}_{1}\right)$ is accepted. Because the 
significance was $0.830>0.05$, thus the Null Hypothesis was accepted and the Alternative Hypothesis was rejected.

\section{DISCUSSION}

From the data analysis on findings, applying the mind mapping technique was not effective to improve students' speaking skills. We can see on the table before and after giving the treatment where the mean score of students after giving the treatment (apply mind mapping) in the Experimental class was 29.73, whereas the mean score of students in the control class (not use mind mapping) was 29.53. It means that after teaching by applying the mind mapping technique in the treatment was not effective to improve students speaking skills. Still, the writer found that students' speaking skills in fluency aspects were better after giving the treatment.

Based on the writer's observation, the students could be motivated and enthusiast in the learning process and also interest to learn because they could create their mind maps. The students felt easy to describe something or someone by using mind mapping. Besides, it had been proved that using mind mapping to teach speaking could help students to learn about describing especially for describing things and persons.

In this research, the speaking test was given to the students that still have basic for English; they are the classes of X MIA 1 and X MIA 2 at MAN Palopo. Besides opportunity after did this research, the writer also found some problem in their classes, such as:

1. The students switch code to speak up because they did not know the English meaning of the words.

2. The students still read the text to speak because they did not memorize the language pattern that had been given. So, it made them difficult to speak without reading the text.

3. They felt hungry, tired, and bored in the class.

4. Some of the students had meetings' organization after they were an exam.

This research is in contrast with some scholars' research findings, namely Afriansya (2019), Alviani (2014), Aquariza (2009), Mirza (2016), Mustajib (2017) who found that using mind mapping as a strategy in teaching English speaking can improve students' speaking ability.

\section{CONCLUSION}

The score of to (t-obtained) that gathered from SPSS 20 shows that t-obtained was higher than t-table (to $>$ ttable). The findings of t-obtained was 0.216 whereas the level of significance of $0.05(5 \%)$ was 2,002. Next, based on the orienting number of significance shows that $0.830>0.05$. Therefore, the Null Hypothesis $\left(\mathrm{H}_{0}\right)$ was accepted and the Alternative Hypothesis $\left(\mathrm{H}_{1}\right)$ was rejected. So, the writer can be concluded that Ho was accepted and Ha was rejected. Using mind mapping to teach speaking skills was not effective because of only improved students' fluency aspect. This research is hoped to give meaningful information to the next researchers. 


\section{ACKNOWLEDGMENT}

The writer thanks to the headmaster, English teacher and the students of MAN Palopo who have participated in this research.

\section{REFERENCES}

Alviani, (2014). Improving Speaking skill through Mind Mapping Technique at the Eighth Year Students of PMDS Putri Palopo. Palopo: STAIN Palopo.

Alviani, R. A. (2014). Implementasi Model PembelajaranKooperative Mind Mapping Terhadap Hasil Belajar Biologi Siswa Kelas VIII SMP Negeri 2 Boyolali Tahun Pelajaran 2013/2014. Surakarta; Universitas Surakarta.

Afriansya, I. (2019). The Effectiveness of Mind Mapping Technique to Teach Students' Speaking Ability at the Tenth-Grade Students of SMAN 1 Jatiwangi in the Academic Year 2017/2018. Journal of English Language Learning, 3(1), 25-33.

Aquariza, N. R. (2009). Using Mind Mapping in Teaching Speaking Skills at RSBI Class $S M A$ Negeri 1 Sidoarjo. Undergraduate thesis. Surabaya: IAIN Sunan Ampel Surabaya.

Brown, D. H. (2001). Teaching by Principle an Interactive Approach to Language Pedagogy. New York: Longman.

Brown, D. H. (2004). Language Assessment: Principle and Classroom Practices. United State of America: Pearson Education, Inc.

Brown, D. H. (2009). Principle of Teaching Speaking skills. Tokyo: Gakue University.

Burns, A. (2013). A holistic approach to teaching speaking in the language classroom. Paper presented at Symposium in University of Stockholm.

Buzan, T., Purwoko, T., \& Susi. (2007). Buku Pintar Mind Map. Jakarta: PT. Gramedia Pustaka Utama.

Edraw. (2018). 3 Basic Types of Mind Maps. http://www.edrawsoft.com/3-basic-mindmap-types.php. Accessed on 16 September 2018.

Estiningrum, D. (2015). Using Talking Chips to Improve VIIA Students' Speaking Skill at SMPN 1 Trucuk in the Academic Year of 2013/2014. Yogyakarta: Yogyakarta State University.

Frey, C. (2010). Power Tips and Strategies for Mind Mapping Software. Innovation Tools. 
Hui, L. (2011). Improving Students' English Speaking Skill through Content Based Intruction. Surakarta: Universitas Surakarta.

Knight, K. (2018). Mind Mapping: Improve Memory, Concentration, Organization, Creativity, and Time Management. Educational Media and Technology Yearbook.

Lackman, K. (2010). Teaching Speaking Sub-Skills. Associates Educational Consultants.

Mirza, A. (2016). The Use of Mind Mapping Strategy to Improve Students' Speaking Ability. Banda Aceh: UIN Ar-Raniry Darussalam Banda Aceh.

Mustajib, A. (2017). Improving the Students' Speaking Ability by Using Mind Mapping and Guided Questions at Fourth Semester of English Education Study Program at Islamic University Indragiri Tembilang. EJI (English Journal of Indragiri) : Studies in Education, Literature and Linguistics, 1(1). https://doi.org/10.32520/eji.v1i1.204.

Putri, L. O. L. (2016). Mind Mapping Sebagai Model Pembelajaran Menilai Penguasaan Konsep dan Alat Evaluasi Menilai Kemampuan Berfikir Kreatif Siswa. Paper presented at Seminar Nasional Pendidikan dan Saintek.

Rini, A. (2012). Excellent English Game. Jakarta: Kesaint Blanc.

Sahrawi. (2013). The Effectiveness of Mind Mapping for Teaching Vocabulary to the Eighth Grade Students of SMA Negeri 3 Sungai Kakap in Academic Year 2012/2013. Jurnal Pendidikan Bahasa, 2(2).

Syam, N., \& Ramlah. (2015). Penerapan Model Pembelajaran Mind Mapping dalam Meningkatkan Hasil Belajar pada Mata Pelajaran Ilmu Pengetahuan Sosial Siswa Kelas IV SDN 54 Kota Parepare. Publikasi Pendidikan, 5(3). https://doi.org/10.26858/publikan.v5i3.1612. 